\title{
Influence of Adaptive Comfort Models in Execution Cost Improvements for Housing Thermal Environment in Concepción, Chile
}

\author{
Alexis Pérez-Fargallo ${ }^{1, *(D)}$, Carlos Rubio-Bellido ${ }^{2}$ (D) and Inmaculada Gallego-Maya ${ }^{2}$ \\ 1 Department of Building Science, University of Bio-Bio, Concepción 4030000, Chile \\ 2 Department of Building Construction II, University of Seville, 41012 Seville, Spain; \\ carlosrubio@us.es (C.R.-B.); igallego1@us.es (I.G.-M.) \\ * Correspondence: aperezf@ubiobio.cl
}

Received: 4 June 2018; Accepted: 4 July 2018; Published: 8 July 2018

\begin{abstract}
Most of the operational energy needed by the housing sector is used to compensate energy losses or thermal gains through the building's envelope. As a result, any improvement in the thermal behavior will provide important opportunities to reduce energy consumption. This research analyzes improvements in the thermal envelope in social housing in the Greater Concepción area in Chile using adaptive thermal comfort models and thermal insulation investments. The objective set out is to evaluate the economic reduction of thermal envelope improvement costs for dwellings, which entails using the adaptive thermal comfort model obtained through monitoring and the surveys applied to the users of social housing in Concepción (CAS), against the international adaptive thermal comfort models established by the EN 15251:2007 and ASHRAE 55-2017 standards. Finally, it is concluded that, on having applied the social housing adaptive thermal comfort model (CAS), execution costs are reduced by between $28.8 \%$ and $58.2 \%$, reaching a time of comfort in free oscillation similar to that obtained from applying the models of the EN 15251:2007 (74.2\%) and ASHRAE 55-2017 standards (59.9\%).
\end{abstract}

Keywords: energy efficiency; adaptive comfort; social housing; thermal environment

\section{Introduction}

The energy consumption of buildings currently ranges between $30 \%$ and $40 \%$ of the world's total consumption [1]. However, it has an upward trend looking towards the future, possibly increasing to 38.4 PWh in 2040 [2]. In this sense, in order to quantify energy consumption within a building, several factors have to be considered at the same time in order to address the thermal comfort requirements: location, envelope features, internal loads, and HVAC equipment [3]. By considering these thermal comfort standards, the energy consumption or indoor temperature of a given space under certain loads can be established. However, it remains crucial to properly define those standards in order to achieve comfort for users while reducing energy consumption [4].

Nowadays, a building's energy performance indicators are associated with the primary energy source consumption, $\mathrm{CO}_{2}$ emissions or net energy distribution, which determine, at the end of the day, the energy efficiency. The EN 15603:2008 and EN 52003-1:2007 standards [5,6] are based on quantifiable parameters associated with the energy consumption. Their evaluation is based on setpoint temperatures and hours of operation, although those fixed temperatures are not suitable for social housing simulations [7], while the performance of these structures should be assessed on the basis of a free running operation or mixed mode in extreme cold or warm conditions. Based on this, the EN 15251:2007 [8] and ASHRAE 55-2017 [9] standards have emerged as a climate adaption 
approach to thermal comfort for naturally ventilated buildings. However, these international norms do not always fit with the specific climate conditions of a region and the energy efficiency improvements and investments should not be representative. Considering this aspect, this research develops an adaptive thermal comfort model for the explicit case of Concepción (Chile), which better fits the economic investments, reducing the energy requirements.

In this sense, the aim of this research is to evaluate the economic reduction that using the adaptive thermal comfort model obtained from monitoring and the surveys (CAS) applied to social housing users in Concepción would have, versus the using the EN 15251:2007 and ASHRAE 55-2017 standards to evaluate the investment cost of thermal improvements in social housing. All this with a final goal of obtaining a total comfort time similar to the free oscillation operating regime.

Considering the case of Chile, more than 3,671,646 subsidies were given between 1964 and 2015 to build social housing, representing around 19 billion euros in investment since 1990 [10]. This data shows a broad view of the substantial investment made to reduce the housing shortage and to improve the quality of life of Chile's poorest sectors. Currently, the legislative instruments to hand over subsidies for housing are governed by Supreme Decrees 01 and 49 [11,12].

The social housing built recently tends to have a built surface area of between 36.00 and $55.00 \mathrm{~m}^{2}$, using detached, semi-detached, terraced houses or blocks. Social housing in Chile considers a standardized geometry which may possibly be due to the surface area limitations considered in Art. 1 of the Statutory Decree $\mathrm{N}^{\circ} 2$ from 1959 on the Housing Plan [13] and budgetary aspects to comply with Article 6.1.2 of the General Construction and Property Development Ordinance [14]. They normally have two or three bedrooms, a living-dining area, kitchen and bathroom. Their constructive characteristics vary depending on the technical application requirements related to where they are built in Chile, being similar to the houses of a given region. In the Bio-Bio Region, when built as detached single-family homes, they tend to consist of light construction systems on a concrete base. The structural walls and roof structure are made from wood using different scantlings, while the external covering is generally made from fiber-cement plates. The internal covering is done using plasterboard while the roof uses corrugated zinc sheets. The window frames are normally made from aluminum or PVC with simple glazing. As a result of their construction systems, they tend to be houses with a low degree of airtightness and with a low thermal inertia [15].

Chile was the first country in Latin America to incorporate EE concepts into its standards, even though these demands had not historically been considered for buildings. Currently, Art. 4.1.10. of the General Building and Property Development Ordinance (OGUC in Spanish) regulates the requirements associated with the thermal transmittance that the house's thermal envelopes must comply with. This article must be complied with, although its requirements are pretty limited [16]. There are also other documents like the Sustainable Construction Code (CCS in Spanish) for Housing, whose requirements are more stringent. However, for the time being, this is only a supporting document, as its compliance is not obligatory [17]. In 2014, a draft bill of the MINVU Technical Standard (NTM 11-2) was prepared. It was developed with the goal of updating the Technical Regulations and Art. 4.1.10 of the OGUC. Some of the thermal demands found in this document are noticeably higher than those established by the OGUC (Table 1).

Table 1. Limitation of transmittances, ventilation and infiltration for Concepcion, OGUC (Art. 4.1.10), Sustainable Construction Code for Housing in Concepcion and MINVU Technical Norm NTM 11-2.

\begin{tabular}{|c|c|c|c|c|c|c|c|c|}
\hline \multirow[b]{2}{*}{ Case } & \multicolumn{3}{|c|}{ U Openings $\left(\mathrm{W} / \mathrm{m}^{2} \mathrm{~K}\right)$} & \multicolumn{3}{|c|}{ U Envelope $\left(\mathrm{W} / \mathrm{m}^{2} \mathrm{~K}\right)$} & \multirow{2}{*}{$\begin{array}{c}\text { Ventilation } \\
\mathrm{L} /(\mathrm{s} \times \text { person })\end{array}$} & \multirow{2}{*}{$\begin{array}{c}\text { Airtightnes } \\
\text { (ACH50) }\end{array}$} \\
\hline & $<21 \%$ & $21-60 \%$ & $60-75 \%$ & Roof & Walls & $\begin{array}{c}\text { Floor } \\
\left(\mathrm{m}^{2} \mathrm{~K}\right) / \mathrm{W} \times 100\end{array}$ & & \\
\hline OGUC & $>3.6$ & $2.4-3.6$ & $<2.4$ & 0.38 & 1.7 & 150 & - & - \\
\hline CCS & - & $2.4-3.6$ & $<2.4$ & 0.33 & 0.5 & 45 & 5.2 & 8 \\
\hline NTM & \multicolumn{2}{|c|}{3.00} & $<3.6$ & 0.33 & 0.5 & 167 & - & - \\
\hline
\end{tabular}


In Chile, energy consumption in the building sector represents $25 \%$ of the state's total energy consumption, and $81 \%$ of this is associated to the residential sector [18]. This may be because of many factors, like the house's age, the construction systems, the user's way of life, the EE of the air-conditioning systems, etc. [19]. 85.6\% of the homes built in Chile to 2008 were built before 2000, the year when the first stage of the Thermal Regulation (RT in Spanish) came into force. Therefore, an important percentage of the buildings does not meet any EE criteria.

Bustamante confirms that, in the future, even new buildings will be subject to reconditioning due to their low EE-associated demands [20]. The same author indicates that the participation of the residential sector in the country's energy consumption is $21.3 \%$, and even with this, most homes fall below comfort temperature limits during winter due to high fuel costs and the low incomes families have. Therefore, it is important to move forward in EE-related aspects and in the habitability of existing and future buildings. Among the environmental factors that affect thermal comfort, one can find air temperature $\left({ }^{\circ} \mathrm{C}\right)$, local radiant temperature $\left({ }^{\circ} \mathrm{C}\right)$ - which plays an important role in the thermal comfort and energy consumption of buildings, especially in the commercial sector [21-23]—along with relative humidity $(\%)$ and air speed $(\mathrm{m} / \mathrm{s})[9,24]$. In addition, there are physiological factors related with the people's heat generation capacity and the capacity to transmit this to the surroundings. This heat generation is fundamentally based on the activity they are doing, as well as the body's insulation level (clo) $[25,26]$. Thermal comfort also varies from person to person, something which is also related to the individual's gender, age, physical condition or socio-economic level. It is possible to find static thermal comfort models where the minimum and maximum comfort temperatures are similar, independent of the user and the weather conditions; for example, the one established in the CCS or in table A.2 of the EN 15251:2007 standard [8,17]. The CCS establishes that the comfort temperature for the southern coastal area where Greater Concepción, a city in the Bio-Bio Region, lies must be between 20 and $27^{\circ} \mathrm{C}$ during the day and between 17 and $27^{\circ} \mathrm{C}$ at night. However, the EN 15251:2007 for residential use determines that the temperature range for category II must be between 20 and $26^{\circ} \mathrm{C}$. It is necessary to point out that said temperature model is not the most appropriate when it comes to evaluating social housing as it does not tend to match their real working operation in free oscillation except in extremely hot or cold situations.

\section{Methodology}

The methodology used consisted of selecting a model with the purpose of studying the thermal improvement of the envelope, to reach the standards of the NTM 11-2. The quantification of the improvements was established by simulating the increased percentage of comfort time which said improvement would mean with the adaptive thermal comfort models of the EN 15251:2007 and ASHRAE 55:2017 standards. Through the iteration of simulations, it was possible to determine what the necessary improvements would be, when targeting a time percentage with the CAS that is similar to the one obtained with the international standards. The iterations on the simulations were done by the parametric analysis of DesignBuilder software, which runs the EnergyPlus simulation procedure. With this program, multiple iterations were carried out automatically with the objective to calibrate percentage of comfort time in free running mode.

Finally, the different improvement scenarios of the thermal envelope defined to reach a similar comfort time in free oscillation with CAS, and those obtained with the application of the EN 15251:2007 and ASHRAE 55-2017, were budgeted for, to evaluate the difference of the execution costs in thermal envelope improvements between the different previously defined improvement scenarios.

In principle, it seems clear that solutions will be conditioned to the case study. Because of this, it is interesting to make a study of specific cases which provide realistic solutions, selecting systems that make it possible to obtain a database that will help the model generate general standards which include the economic criteria. As such, it is necessary to assess the system's viability by using sets of measures, establishing optimal affordability levels as established in European Regulation (EU) No. 244/2012 [27,28]. 
The cost calculation of the improvements are made by taking into account the basis of the ASTM E918:2015 [29], which considers the thermal insulation per square meter from established building construction systems for a building type and specific intervention $[27,28]$. To obtain the overall costs, the materials, manpower and applicable social laws in Chile (increase of $40 \%$ on the manpower price per hour) were taken into account. These concepts form the direct cost. In order to obtain the overall costs, the overhead costs ( $20 \%$ of the direct costs) and VAT ( $19 \%$ of the direct cost, plus overheads) were added. Please note that the overall costs do not include costs that are supposed to be similar in all cases (maintenance costs, common materials, etc.). The ABACO Project database was used for the cost evaluation [30]. This database focuses on the Chilean context and was supported by the Chilean Economic Development Agency (CORFO).

\subsection{Case study Model}

The model home used for the case study is a standard social home of $50.48 \mathrm{~m}^{2}$ spread over two levels. It is formed of a living room, a dining room, two bedrooms, a bathroom and a kitchen, and is located in Concepción, Chile (Figure 1). The initial characteristics considered for the home's envelope can be seen in Table 2. The glazing system the model home has in its base case considers $6 \mathrm{~mm}$ simple glazing. The thermal loads associated to the electronic equipment were determined using the values established in the CCS in terms of percentage surface area in square meters that the home has $\left(8.9 \mathrm{~W} / \mathrm{m}^{2}\right)$. The number of people to consider for the thermal loads associated to the occupation is given by the number of bedrooms. In this case, with two bedrooms, a total of three people is considered. The occupation loads, equipment and lighting calendars are established according to CCS [17] (Figure 2). The minimum ventilation forced extraction levels will be 5 renew $/ \mathrm{h}$ [17]. The glazing system the model home has in its base case considers $6 \mathrm{~mm}$ simple glazing.

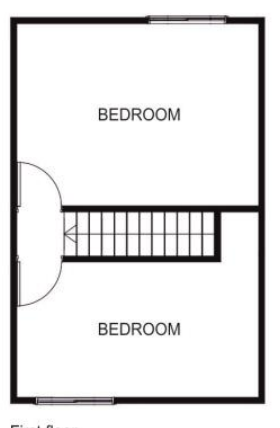

First floor

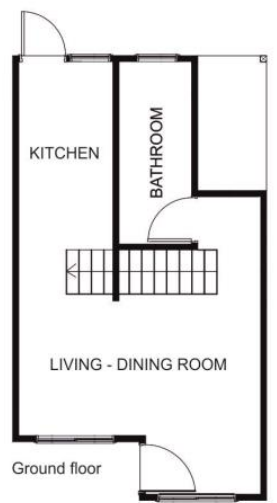

(1)

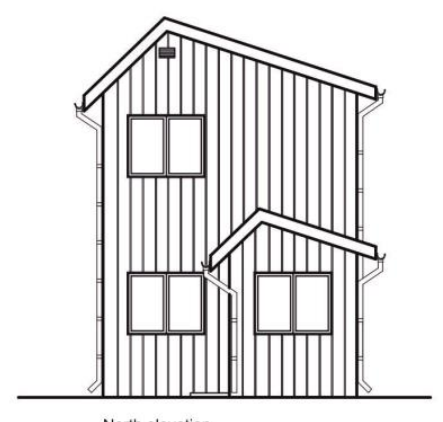

North elevation

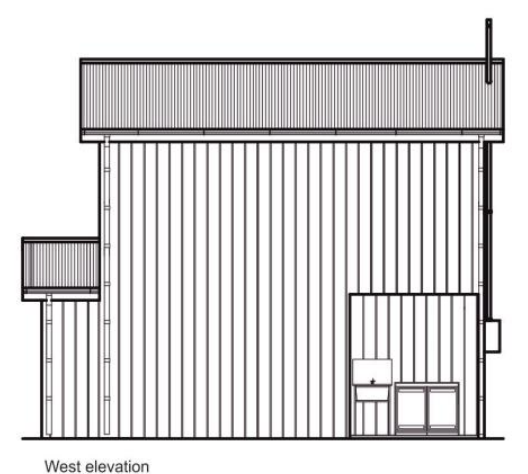

West elevation

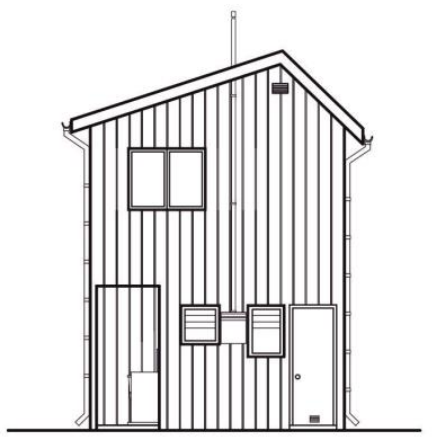

South elevation

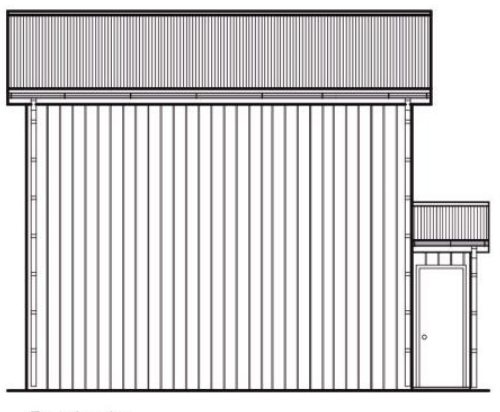

East elevation

Figure 1. Housing model for the study. 
Table 2. Thermal transmittance of the construction systems the model home has in comparison with the thermal demands of the NTM.

\begin{tabular}{|c|c|c|c|c|c|}
\hline \multirow{2}{*}{\multicolumn{2}{|c|}{ Elements }} & \multicolumn{2}{|c|}{ Walls } & \multirow{2}{*}{ Roof } & \multirow{2}{*}{ Floor } \\
\hline & & Ground Floor & Top Floor & & \\
\hline \multicolumn{2}{|c|}{ External covering } & \multicolumn{2}{|c|}{ Smart panel SR8 e = $11.1 \mathrm{~mm}$} & $\begin{array}{l}\text { Zinc-aluminum sheets } \\
3660 \times 851 \times 0.35 \mathrm{~cm}\end{array}$ & $\begin{array}{c}\text { Gravel e }=8 \mathrm{~cm} \\
\text { Sand } \mathrm{e}=5 \mathrm{~cm}\end{array}$ \\
\hline \multicolumn{2}{|c|}{ Structure } & $\begin{array}{c}\text { Brickwork } \\
24 \times 11.5 \times 7.1 \mathrm{~cm}\end{array}$ & $\begin{array}{l}\text { Pine IPV } 2 \times 3^{\prime \prime} \\
\quad @ 0.40 \mathrm{~m}\end{array}$ & $\begin{array}{l}\text { Pine IPV } 2 \times 2 " \\
\quad @ 0.40 \mathrm{~m}\end{array}$ & Concrete base $\mathrm{e}=10 \mathrm{~cm}$ \\
\hline \multicolumn{2}{|c|}{ Internal covering } & \multicolumn{3}{|c|}{ Plasterboard $10 \mathrm{~mm}$} & Ceramic base $45 \times 45 \mathrm{~cm}$ \\
\hline Base & $\mathrm{U}\left[\mathrm{W} / \mathrm{m}^{2} \mathrm{k}\right]$ & 1.23 & 2.04 & 3.67 & 1.83 \\
\hline NTM & $\mathrm{U}\left[\mathrm{W} / \mathrm{m}^{2} \mathrm{k}\right]$ & 0.50 & & 0.33 & 0.60 \\
\hline \multicolumn{2}{|c|}{ Insulation } & $\begin{array}{c}\text { Extruded } \\
\text { Polystyrene [XPS] }\end{array}$ & Mineral wool & Mineral wool & $\begin{array}{l}\text { Extruded Polystyrene } \\
\text { [XPS] }\end{array}$ \\
\hline \multicolumn{2}{|c|}{ Thickness (mm) } & 40 & 100 & 120 & 30 \\
\hline \multicolumn{2}{|c|}{$\operatorname{AREA}\left(\mathrm{m}^{2}\right)$} & 50.97 & 84.70 & 24.60 & 24.60 \\
\hline \multicolumn{2}{|c|}{ Price $\left(€ / \mathrm{m}^{2}\right)$} & 26.63 & 59.12 & 55.56 & 15.57 \\
\hline \multicolumn{2}{|c|}{ Total cost $(€)$} & 1357.45 & 2760.47 & 1366.71 & 382.97 \\
\hline
\end{tabular}

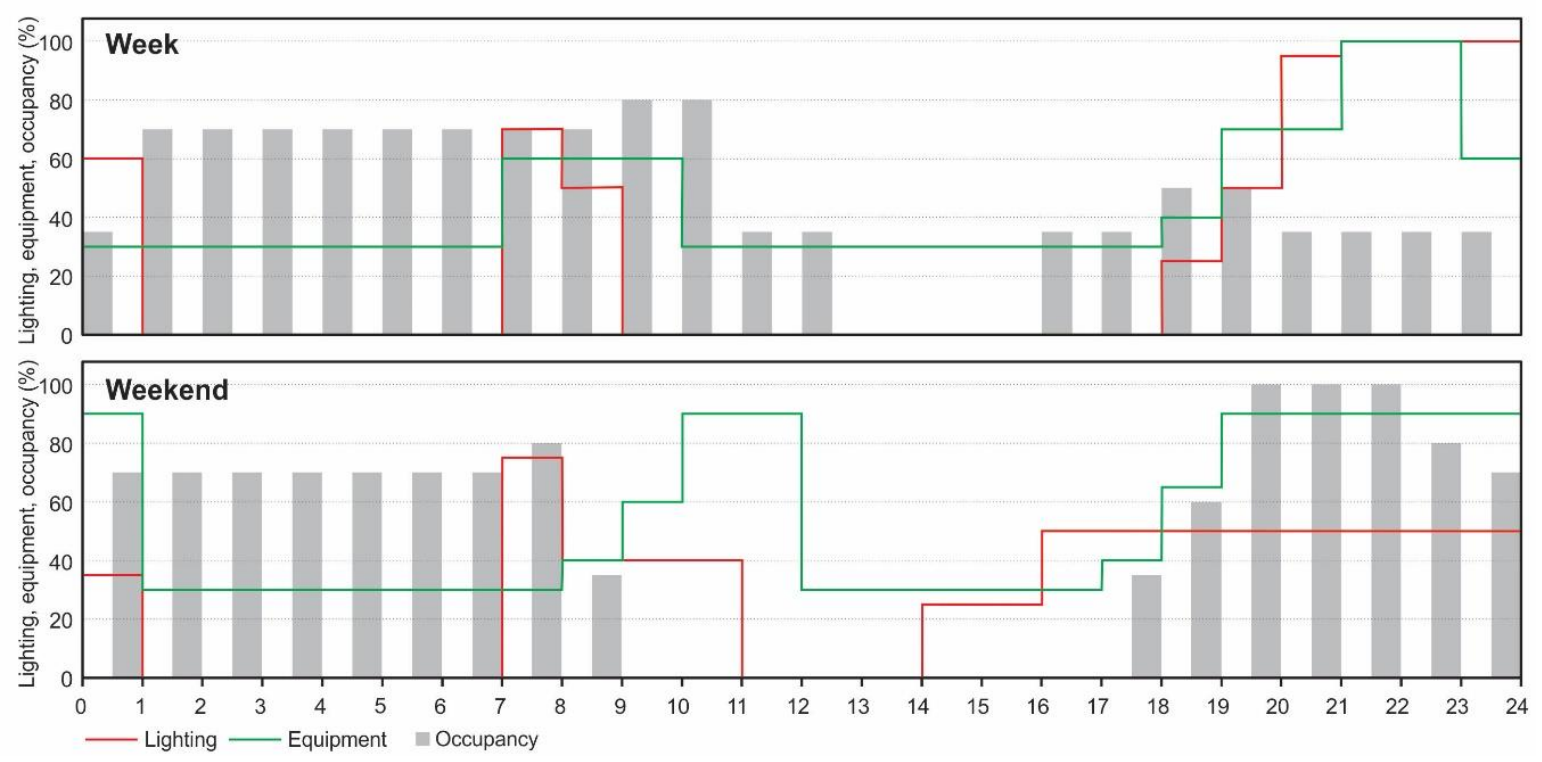

Figure 2. Occupation, lighting and equipment and ventilation schedules.

The thermal improvement from the minimum compliance of the standard's demands is mainly characterized by the inclusion of insulation in the wall and roof elements along with the floor elements in contact with the ground (Table 2). The model home's base structure was modified, respecting the essential materials that characterize it until meeting the standards demanded by the MINVU Technical Standard (NTM 11-2). In this sense, the top floor's walls were modified to install $100 \mathrm{~mm}$ mineral wool. The thickness increase is made with a $1 \times 2$ " slat pine on the $2 \times 3$ " structure to reach the thickness needed to install the insulation.

\subsection{Adaptive Thermal Comfort Approach}

Comfort evaluation in moderate thermal environments can also be made based on two theories, namely the adaptive theory and the thermal balance theory [31,32]. These methods were developed starting from mathematical models that allow making an estimation and predicting the appropriate conditions the people would have to be in, to obtain the thermal quality of their environment. 
The adaptive theory is based on individuals' adaptation capabilities to the thermal conditions. Said adaptation may be metabolic, by wearing clothing or by opening and closing windows. Numerous field experiments have shown that occupants' thermal responses in naturally ventilated spaces depend partially on the outside weather and differ from the thermal responses of occupants of buildings with air-conditioning systems. This is mainly due to differences in the thermal experience, availability of control and changes in the occupant's expectations [8]. The evaluation's models come from the questionnaires made to a sample of individuals. These are based on questions about the environment, where the subject associates their responses to a scale of values, and these to a comfort scale $[4,33,34]$. The most extensive adaptive comfort models, ASHRAE 55-2017 and EN 15251:2007, were established from the RP-884 and SCATs (Smart Control and Thermal Comfort, SCATs) research projects [8,32,35]. These models are applied in buildings without active systems, where there is easy access to operable windows and the occupants can adapt their clothing to the thermal conditions. Both models establish that the occupant's metabolic activity must be between 1.0 and 1.3 met, and where it is possible to adapt the clothing level between 0.5 and 1.0 clo. In the same way, the average external temperatures of the previous 7 days are used both for the calculation of the average operation temperature, $\theta_{r m}$, of a certain day, with $\theta_{e d-1}$ being the average external temperature of the previous day, $\theta_{e d-2}$ the average external daily temperature of the day before day $\theta_{e d-1}$, and so on using Equation (1).

$$
\theta_{r m}=\left(\theta_{e d-1}+0.8 \times \theta_{e d-2}+0.6 \times \theta_{e d-3}+0.5 \times \theta_{e d-4}+0.4 \times \theta_{e d-5}+0.3 \times \theta_{e d-6}+0.2 \times \theta_{e d-7}\right) / 0.8
$$

\subsubsection{Adaptive Thermal Comfort Model of the EN 15251:2007 Standard}

According to the EN 15251:2007 standard, four types of internal comfort classifications are established based on the occupant's expectations, as well as other factors that condition the perception of comfort, along with the building's age [4,36-38] (Table 3).

Table 3. Expectation categories addressed in EN 15251:2007.

\begin{tabular}{cl}
\hline Category & \multicolumn{1}{c}{ Detail } \\
\hline I & $\begin{array}{l}\text { High level of expectation, recommended for spaces occupied by weak and sensitive people } \\
\text { with special requirements like handicapped, sick, elderly and very young children. }\end{array}$ \\
\hline II & Normal level of expectation; should be used for new and renovated buildings. \\
\hline III & Acceptable and moderate level of expectation; It can be used in existing buildings. \\
\hline IV & $\begin{array}{l}\text { Values outside of the criteria of the preceding categories. This category should only be } \\
\text { accepted during a limited part of a year. }\end{array}$ \\
\hline
\end{tabular}

The comfort evaluation is made for each one of the categories using the Table 4 equations. The temperature evaluation, starting from the aforementioned model, is valid for office buildings and other similar buildings [21-23] that are primarily used for human occupation with mainly sedentary activities and homes. The average operation temperature for its application, $\theta_{r m}$, must be between 10 and $30^{\circ} \mathrm{C}$ for the upper limits and between 15 and $30^{\circ} \mathrm{C}$ for the lower ones (Table 4).

Table 4. Comfort temperature ranges per category in regard to prevailing mean outdoor air temperature $\left(\theta_{r m}\right)$ EN 15251:2007.

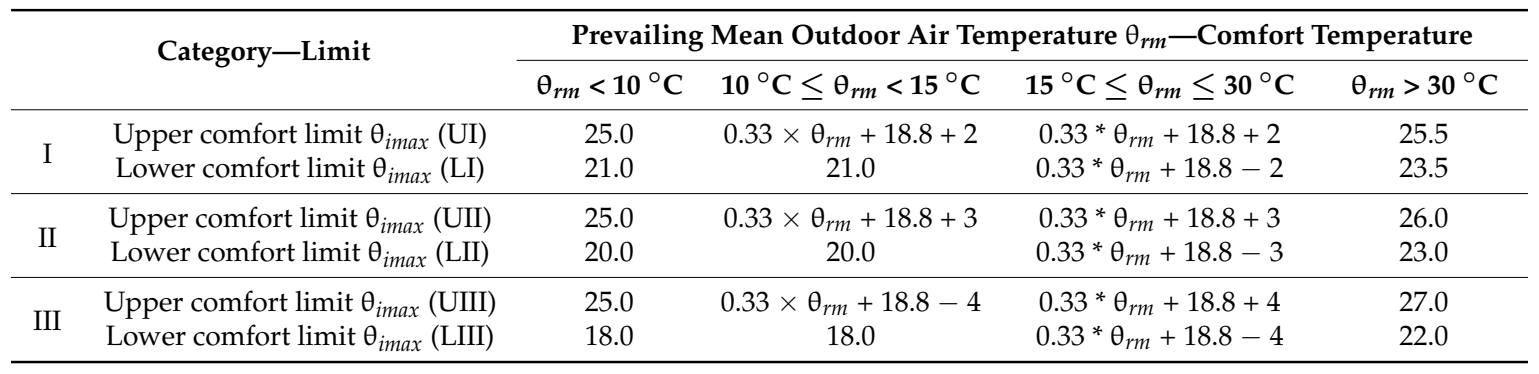




\subsubsection{Adaptive Thermal Comfort Model of the ASHRAE 55-2017 Standard}

In the case of ASHRAE 55-2017, two comfort levels are established based on the occupant's acceptability percentage: the first is associated with typical demand levels of $80 \%$ and the second when a higher level of comfort is required, with said percentage being $90 \%$.

The ASHRAE adaptive comfort model's evaluation is made based on the comfort demands using the Table 5 equations. The graphical representation of said formulas is found in Table 5 . The temperature's evaluation using the described model is valid for buildings for human occupation with sedentary activities and metabolic values within a 1.0 to 1.3 range, just as in the EN standard's model. For its application, the average operation temperature, $\theta_{r m}$, must be between 10 and $33.5^{\circ} \mathrm{C}$ (Table 5).

Table 5. Comfort temperature ranges per acceptability in regard to prevailing mean outdoor air temperature $\left(\theta_{r m}\right)$ ASHRAE 55-2017.

\begin{tabular}{llccc}
\hline \multirow{2}{*}{ Acceptability-Limit } & \multicolumn{3}{c}{ Prevailing Mean Outdoor Air Temperature $\theta_{r m}$-Comfort Temperature } \\
\cline { 3 - 5 } & & $\boldsymbol{\theta}_{r m}<\mathbf{1 0}{ }^{\circ} \mathbf{C}$ & $\mathbf{1 0}{ }^{\circ} \mathbf{C} \leq \theta_{r m} \leq \mathbf{3 3 . 5}{ }^{\circ} \mathbf{C}$ & $\boldsymbol{\theta}_{r m}>\mathbf{3 3 . 5}{ }^{\circ} \mathbf{C}$ \\
\hline \multirow{2}{*}{$90 \%$} & Upper comfort limit $\theta_{\text {imax }}(\mathrm{U} 90 \%)$ & 23.4 & $0.31 \times \theta_{r m}+17.8+2.5$ & 30.7 \\
& Lower comfort limit $\theta_{\text {imax }}(\mathrm{L} 90 \%)$ & 18.4 & $0.31 \times \theta_{r m}+17.8-2.5$ & 25.7 \\
\hline \multirow{2}{*}{$80 \%$} & Upper comfort limit $\theta_{\text {imax }}(\mathrm{U} 80 \%)$ & 24.4 & $0.31 \times \theta_{r m}+17.8+3.5$ & 26.0 \\
& Lower comfort limit $\theta_{\text {imax }}(\mathrm{L} 80 \%)$ & 17.4 & $0.31 \times \theta_{r m}+17.8-3.5$ & 24.7 \\
\hline
\end{tabular}

\subsubsection{Thermal Comfort Model Obtained from the Surveys (CAS)}

The preparation of the FONDECYT 3160806 project's CAS model was developed from thermal comfort surveys answered by users of social housing while monitoring, in parallel, the internal and external temperatures. The target group was chosen on a basis of being dwellings which benefited from any type of government subsidy, i.e., social dwellings. All types were included in the survey, which comprised 6 single dwellings, 6 row houses, 25 detached houses and 3 apartments located in condominiums, giving a total of 40 dwellings.

Residents from these dwellings were surveyed over 7 months (April to October, 2016), as this is the period when the temperatures are lower. A total of 709 surveys were made with 121 people (roughly 3 people per household). Their ages ranged from 14 to $84 ; 57$ of them were men and there were 64 women. The thermal comfort surveys were based on standardized methods $[9,33]$. In the first part of the survey, the users were asked to inform about their clothing, their activity and the position in which the survey was being answered. After that, they had to score about their Thermal Sensation Vote (TSV), Thermal Preference Vote (TPV) and their Thermal Acceptability (TA). In total, a final number of 657 valid questionnaires were filled out. An average of 17.72 per household.

Data collection was performed using a weather station for outdoors (Vantage Pro 2) and a measuring cell model Delta Ohm HD 32.3 for indoors, which records dry bulb temperature (Ta), globe temperature (Tg), relative humidity (HR), and air speed (Va) in intervals of $5 \mathrm{~min}$. The dwellings were monitored during the coldest months, so that information about the resident's comfort demand could be gathered when the average outdoor temperature was below $15^{\circ} \mathrm{C}$ and $10^{\circ} \mathrm{C}$. These figures were established following the lower limits of the EN 15251:2007 standard, under which the lower limit for the three categories of thermal comfort is constant, thus adaptive comfort is not applicable [8]. In a similar fashion, ASHRAE 55-2017 establishes that both the upper and lower limit for thermal comfort for acceptability levels of both $80 \%$ and $90 \%$ should be a constant and, therefore, adaptive comfort is not valid [9].

The model, just like the EN and ASHRAE adaptive comfort models, was created starting from the regression of values obtained from the user's comfort temperature calculation [34]. This comfort temperature has been obtained from the user's votes and the operational temperature of the space when the survey was made. Just like in the previous models, it uses the average operation temperature 
calculation, $\theta_{r m}$, of a given day, obtained from the average external temperatures of the previous 7 days.

The CAS adaptive comfort model's evaluation is made based on the comfort demands using the Table 6 equations. The assessment of the temperatures under this model is valid for buildings used for human occupation with sedentary activities and metabolic values in a 1.0 to 1.3 range, just as in the EN and ASHRAE standards' model. Again, the space must have easy access to operable windows with the occupants being able to freely adapt their clothing to the external and/or internal thermal conditions. For its application, the average operation temperature, $\theta_{r m}$, must be between 5 and $12{ }^{\circ} \mathrm{C}$ (Table 6).

Table 6. Comfort temperature ranges in regard to prevailing mean outdoor air temperature $\left(\theta_{r m}\right)$ of the CAS adaptive comfort model.

\begin{tabular}{llccc}
\hline & & Prevailing Mean Outdoor Air Temperature $\theta_{r m}$-Comfort Temperature \\
\hline \multirow{2}{*}{$90 \%$} & Acceptability—Limit $\left({ }^{\circ} \mathbf{C}\right)$ & $\mathbf{0}^{\circ} \mathbf{C} \leq \theta_{r m}<5$ & $\mathbf{5}^{\circ} \mathbf{C} \leq \theta_{r m} \leq \mathbf{6 . 5}$ & $\mathbf{6 . 5}{ }^{\circ} \mathbf{C}<\theta_{r m} \leq \mathbf{1 2}$ \\
\hline \multirow{2}{*}{$80 \%$} & Upper comfort limit $\theta_{i \max }(\mathrm{U} 90 \%)$ & 20.25 & $0.115 \times \theta_{r m}+19.67$ & $0.678 \times \theta_{r m}+16.01$ \\
& Lower comfort limit $\theta_{i \max }(\mathrm{L} 90 \%)$ & 15.25 & $0.115 \times \theta_{r m}+14.67$ & $0.678 \times \theta_{r m}+11.01$ \\
\hline \multirow{2}{*}{ Upper comfort limit $\theta_{\text {imax }}(\mathrm{U} 80 \%)$} & 21.75 & $0.115 \times \theta_{r m}+21.17$ & $0.678 \times \theta_{r m}+17.51$ \\
& Lower comfort limit $\theta_{i \max }(\mathrm{L} 80 \%)$ & 13.75 & $0.115 \times \theta_{r m}+13.17$ & $0.678 \times \theta_{r m}+9.51$ \\
\hline
\end{tabular}

\section{Results}

\subsection{Housing Behavior with and without Thermal Insulation}

The increase of thermal insulation in buildings does not always have the expected result. In some cases, the excessive thermal insulation causes overheating problems. As can be seen in Figure 3, the temperature without thermal insulation surpasses the upper and lower limits of the EN 15251:2007 Category III, ASHRAE 55-2017 and CAS models in $46.6 \%$, $46.5 \%$ and $30.0 \%$ of the hours of the year, respectively. The discomfort problem is mainly associated to the cold in the EN and ASHRAE standards, being $42.9 \%$ and $37.6 \%$, respectively. However, in the CAS model, the percentage of time where the temperature is below the lower limit is $21.0 \%$; that is, $1839 \mathrm{~h}$ of the 8760 of a year and just $785 \mathrm{~h}$ are above the upper limit. Temperatures range from $9.2^{\circ} \mathrm{C}$ to $30.4{ }^{\circ} \mathrm{C}$ with a total amplitude of $21.2^{\circ} \mathrm{C}$ (Figure 3).

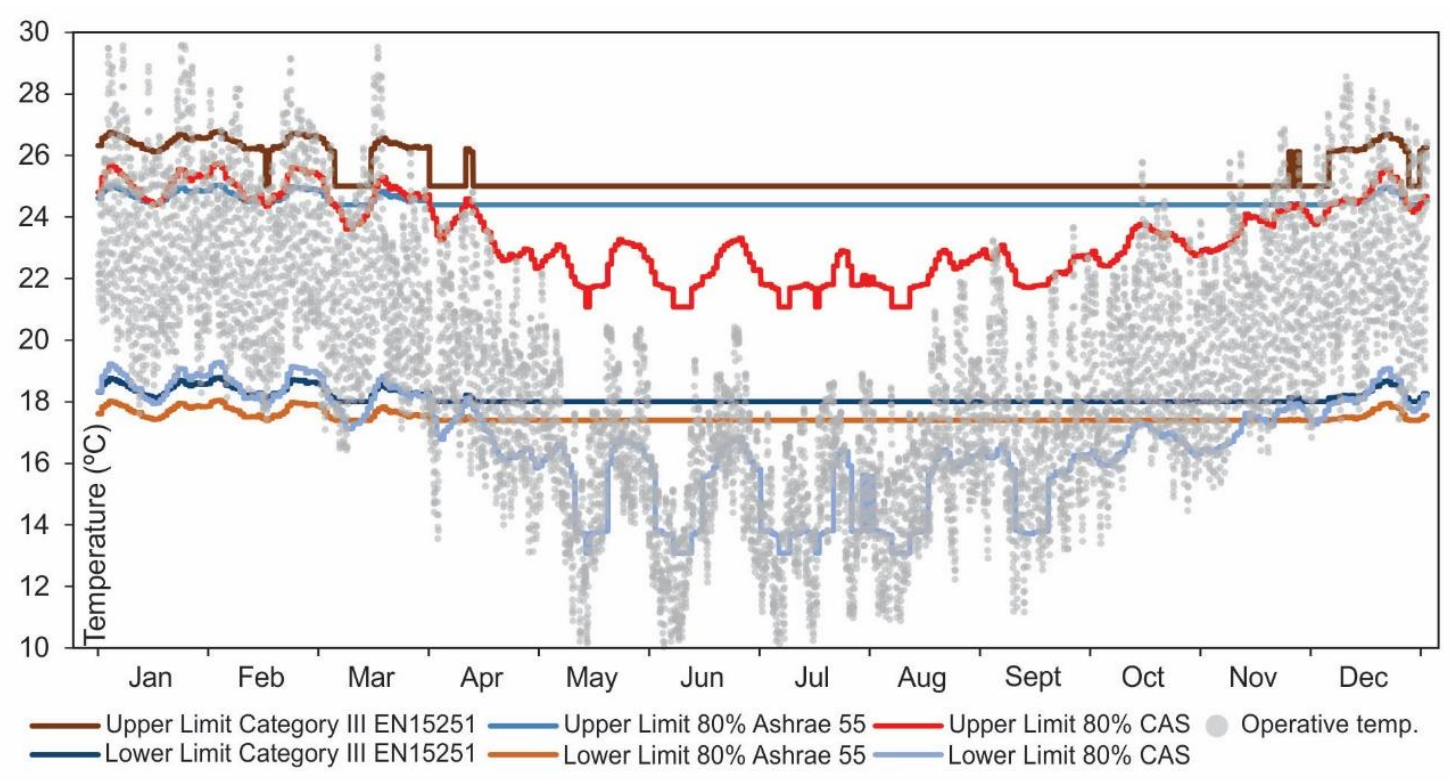

Figure 3. Operative temperature and average outdoor air temperature with regard to the limits addressed in CAS, ASHRAE 55-2017 and EN 15251:2007. Housing without thermal insulation. 
The implementing of insulation to meet NTM 11 requirements denotes three effects. On one hand, the hours of cold discomfort situations are reduced in the three adaptive comfort models; $4.9 \%$ (EN), $2.9 \%$ (ASHRAE) and $0 \%$ (CAS) (Figure 4). However, the warm discomfort hours are increased, 20.9\%, $37.2 \%$ and $47.8 \%$ respectively. Temperatures range from $15.1^{\circ} \mathrm{C}$ to $30.7^{\circ} \mathrm{C}$ with a total amplitude of $15.5^{\circ} \mathrm{C}$. Therefore, annual and daily thermal oscillation are reduced $\left(5.7^{\circ} \mathrm{C}\right)$ (Figures 2 and 3 ).

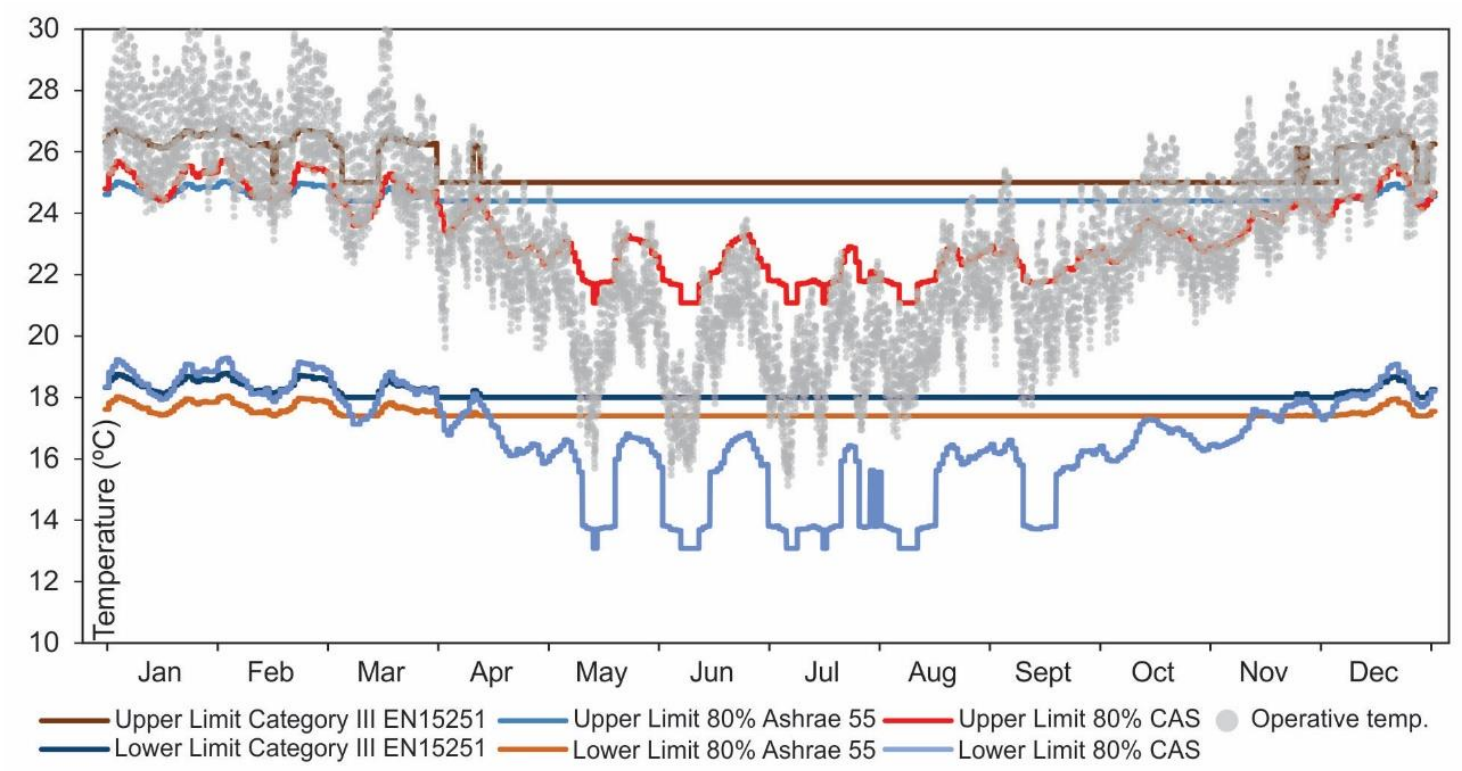

Figure 4. Operative temperature and average outdoor air temperature with regard to the limits addressed in CAS, ASHRAE 55-2017 and EN 15251:2007. Housing with thermal insulation to meet NTM 11 requirements.

The thermal insulation implementation to meet NTM 11 requirements reduces cold situations in the three models; $38.00 \%$ (EN), 34.8\% (ASHRAE) and $21.0 \%$ (CAS) (Figure 4), and the overheating is increased $17.3 \%, 28.4 \%$ and $38.8 \%$, respectively. Therefore, comfort temperatures increase in the EN model (20.8\%) and ASHRAE (6.4\%). However, in the CAS model, comfort temperatures are reduced $(17.8 \%)$, since it is a model that is more restrictive to high temperatures. The total percentage of time in comfort conditions is $74.2 \%, 59.9 \%$ and $52.2 \%$, respectively.

\subsection{ASHRAE 55-2017 versus CAS}

Once the necessary improvements were identified, these were simulated in DesignBuilder, to obtain the operational temperatures and to know how long the house fell within the ASHRAE 55-2017's 80\% limits. The ensuing results, established that the thermal comfort percentage obtained, applying the ASHRAE 55-2017 international norm, was 59.9\%. Therefore, the application of NTM 11-2 to social housing in the city of Concepcion would suppose, according to ASHRAE, that for a standard year, the users would be in comfort for approximately half the hours of the year.

The purpose of giving a value to the economic reduction in the investment cost of thermal improvements, that using the monitoring and survey (CAS)-based adaptive thermal model versus the ASHRAE 55-2017 would imply, to get a similar thermal comfort time, first establishing the thermal improvement needed to comply with the NTM 11 to determine what the improvement demand would be.

By means of parametric simulation, it is established that reducing the thickness of thermal insulation by $10 \mathrm{~mm}$ in the ground floor walls, $25 \mathrm{~mm}$ in the top floor, $20 \mathrm{~mm}$ in the roof and $10 \mathrm{~mm}$ in the floor, CAS comfort is $64.0 \%$ (Table 7 and Figure 5). Under this model, the percentage of time above the comfort upper limit is $24.9 \%$ and there are no hours in the cold situation. Considering ASHRAE, 
the percentage of time in comfort is $63.8 \%$ with $30.9 \%$ of the time above the upper limit and $5.3 \%$ of the hours below the lower limit.

Table 7. Modifications of the thermal improvement applying CAS to reach the same comfort percentage as with the NTM 11-2 applying ASHRAE 55-2017.

\begin{tabular}{|c|c|c|c|c|c|c|c|}
\hline \multirow{2}{*}{ Elements } & \multirow{2}{*}{ Insulation } & \multicolumn{3}{|c|}{ NTM 11-2 } & \multicolumn{3}{|c|}{ CAS } \\
\hline & & $\begin{array}{c}\text { Thickness } \\
(\mathrm{mm})\end{array}$ & $\begin{array}{l}\text { Price } \\
\left(€ / \mathrm{m}^{2}\right)\end{array}$ & $\begin{array}{c}\text { Total Cost } \\
(€)\end{array}$ & $\begin{array}{c}\text { Thickness } \\
(\mathrm{mm})\end{array}$ & $\begin{array}{l}\text { Price } \\
\left(€ / \mathrm{m}^{2}\right)\end{array}$ & $\begin{array}{c}\text { Total Cost } \\
(€)\end{array}$ \\
\hline Ground floor w. & XPS & 40 & 26.63 & 1357.45 & 30 & 20.81 & 1060.67 \\
\hline Top floor w. & Mineral wool & 100 & 59.12 & 2760.47 & 75 & 32.33 & 1509.51 \\
\hline Roof & Mineral wool & 120 & 55.56 & 1366.71 & 100 & 53.98 & 1327.89 \\
\hline Floor & XPS & 30 & 15.57 & 382.97 & 20 & 11.26 & 277.07 \\
\hline \multicolumn{2}{|c|}{ Total Cost (EUR) } & & 5867.59 & & & 4175.13 & \\
\hline
\end{tabular}

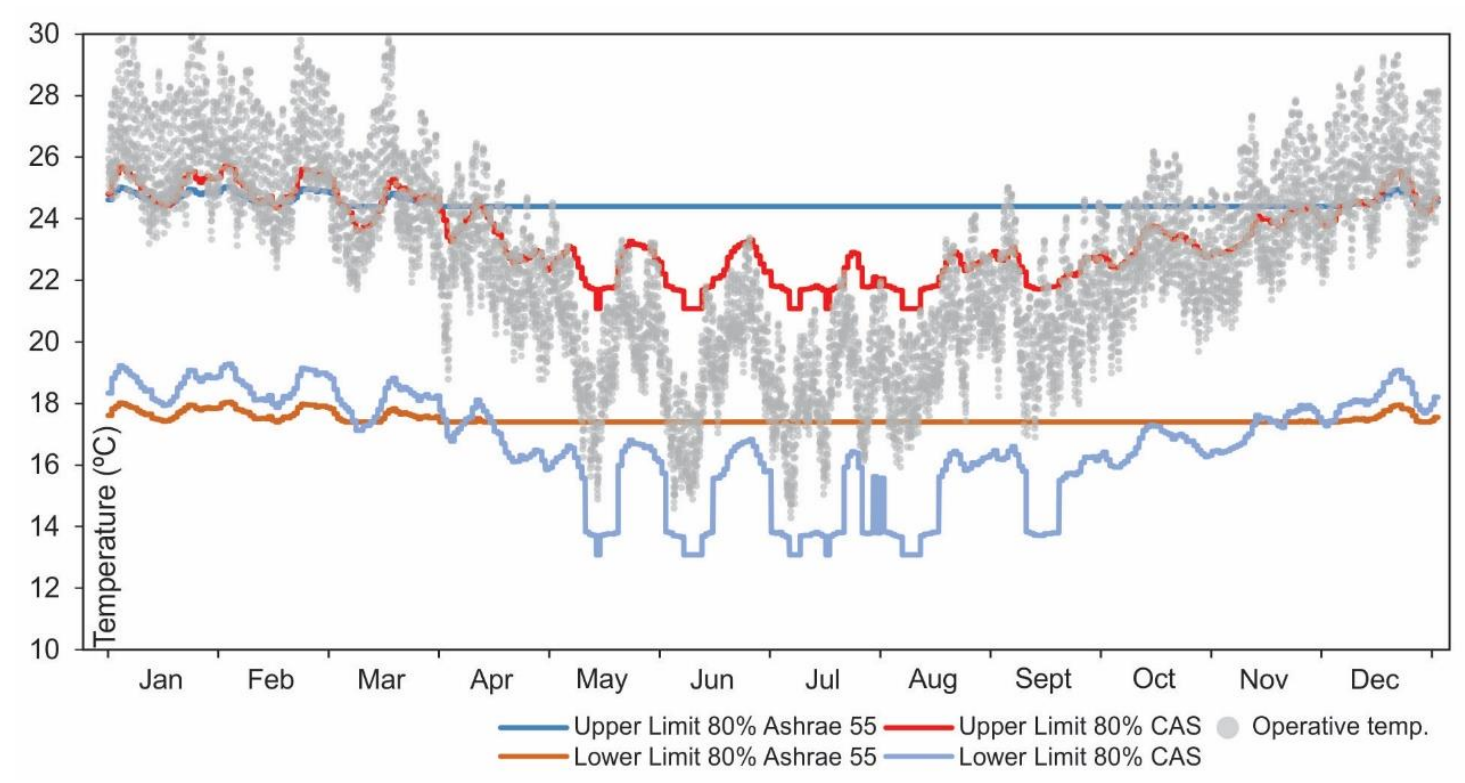

Figure 5. Operative temperature and average outdoor air temperature with regard to the limits addressed in CAS and ASHRAE 55-2017. Housing with thermal insulation improvement applying CAS to reach the same comfort percentage than NTM 11-2 applying ASHRAE 55-2017.

The insulation thickness reduction related to the NTM 11-2 requirements produced an increase in the ASHRAE comfort hours of 3.9\% and in CAS of $11.7 \%$. Hence, surpassing by $4.1 \%$, the $59.9 \%$ value obtained by applying ASHRAE in the previous section. Annual temperatures range between $14.3^{\circ} \mathrm{C}$ and $30.3^{\circ} \mathrm{C}$, with an amplitude of $16.0^{\circ} \mathrm{C}$. Thus, the minimum temperature would drop $0.9^{\circ} \mathrm{C}$, the maximum temperature, $0.3{ }^{\circ} \mathrm{C}$ and the annual oscillation, $0.5^{\circ} \mathrm{C}$, with regard to the case that complies with the NTM 11's insulation thickness. It is shown, however, that such reductions are not relevant.

To calculate the improvement costs for the pine structure which affects the first floor of the model home, it must be considered that it is necessary to increase its thickness from $3^{\prime \prime}$ to 4 ", conditioned by the thickness of the insulation using $100 \mathrm{~mm}$ mineral wool. Under this assumption, said thickness would be reduced to $75 \mathrm{~mm}$, which means that said structure is not modified pursuant to the base structure (Table 7).

The reduction of the insulation investment costs is $21.9 \%$ for the ground floor wall, $45.3 \%$ for the top floor wall, $2.8 \%$ for the roof and $27.7 \%$ for the floor. The total reduction cost is $28.8 \%$ (Table 7 ). Therefore, it can be seen that with a significant reduction of the investment costs, an even greater 
comfort percentage of time can be obtained $(63.8 \%$ with CAS) with a slight increase of the minimum and maximum temperatures $\left(0.9^{\circ} \mathrm{C}\right.$ and $\left.0.3^{\circ} \mathrm{C}\right)$.

\subsection{EN 15251:2007 versus CAS}

The percentage of time in comfort obtained in the home with the application of the improvements to meet the NTM 11-2, evaluated via category III of the adaptive comfort model of the EN 15251:2007 norm, is $74.2 \%$.

It is established, by means of parametric simulation, that eliminating the insulation of the ground floor walls and ground and by reducing to $40 \mathrm{~mm}$ the top floor and roof insulation, the percentage of time in comfort by applying CAS, is $87.1 \%$ (Table 8 and Figure 6). Under this model, the percentage of time above the comfort upper limit is $12.9 \%$ and there are no hours in cold situation. Regarding EN, the percentage of time in comfort is $80.5 \%$ with $3.2 \%$ of the time above the upper limit and $16.2 \%$ of the hours below the lower limit. This is $6.6 \%$ higher than the adaptive thermal comfort time if CAS is used.

Table 8. Modifications of the thermal improvement applying CAS to reach the same comfort percentage as the NTM 11-2 applying EN 15251:2007.

\begin{tabular}{|c|c|c|c|c|c|c|c|}
\hline \multirow{2}{*}{ Elements } & \multirow{2}{*}{ Insulation } & \multicolumn{3}{|c|}{ NTM 11-2 } & \multicolumn{3}{|c|}{ CAS } \\
\hline & & $\begin{array}{l}\text { Thickness } \\
\text { (mm) }\end{array}$ & $\begin{array}{l}\text { Price } \\
\left(€ / \mathrm{m}^{2}\right)\end{array}$ & $\begin{array}{c}\text { Total Cost } \\
(€)\end{array}$ & $\begin{array}{c}\text { Thickness } \\
\text { (mm) }\end{array}$ & $\begin{array}{l}\text { Price } \\
\left(€ / \mathrm{m}^{2}\right)\end{array}$ & $\begin{array}{c}\text { Total cost } \\
(€)\end{array}$ \\
\hline Ground floor w. & XPS & 40 & 26.63 & 1357.45 & - & - & - \\
\hline Top floor w. & Mineral wool & 100 & 59.12 & 2760.47 & 60 & 28.15 & 1314.43 \\
\hline Roof & Mineral wool & 120 & 55.56 & 1366.71 & 80 & 46.32 & 1139.35 \\
\hline Floor & XPS & 30 & 15.57 & 382.97 & - & - & - \\
\hline \multicolumn{2}{|c|}{ Total cost (EUR) } & & 5867.59 & & & 2453.78 & \\
\hline
\end{tabular}

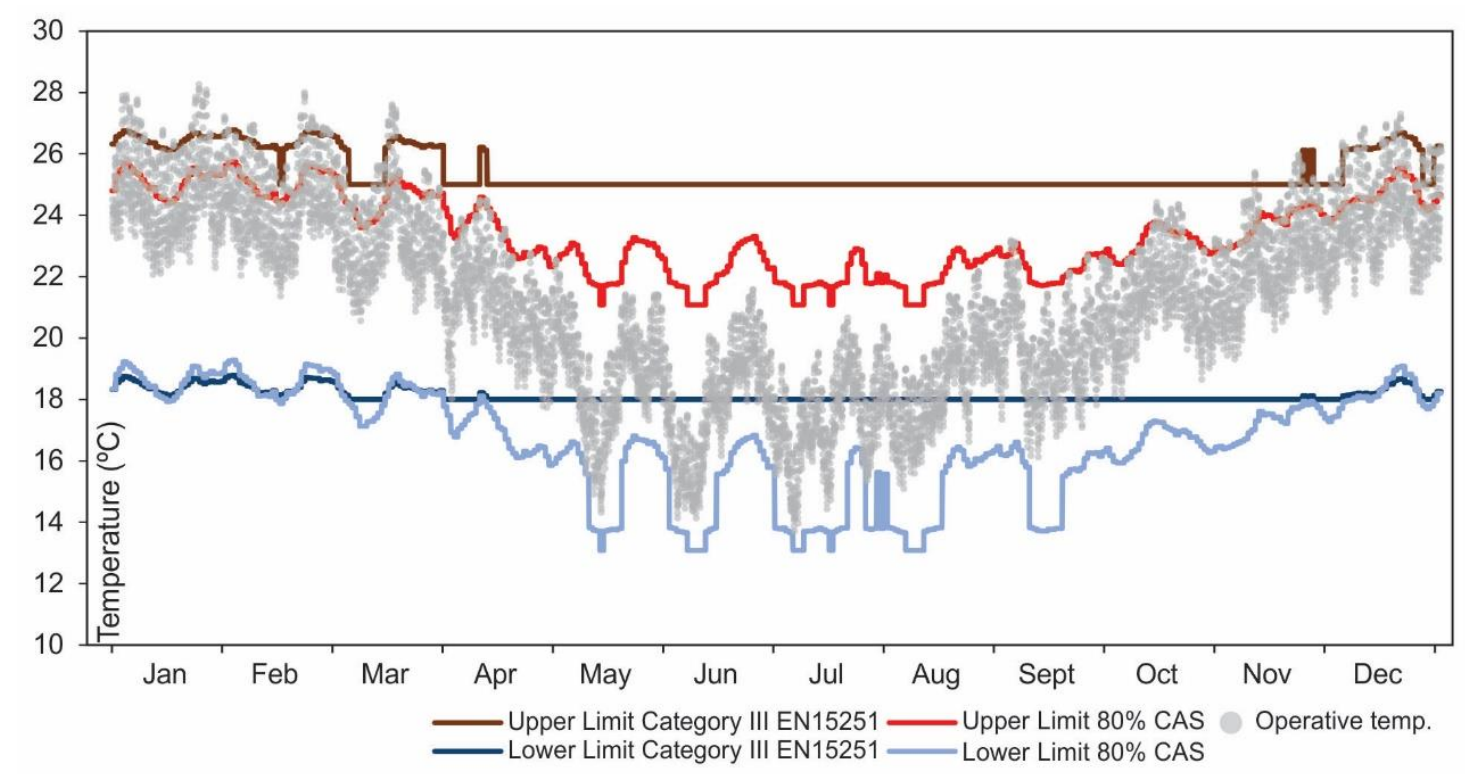

Figure 6. Operative temperature and average outdoor air temperature with regard to the limits addressed in CAS and EN 15251:2007. Housing with thermal insulation improvement applying CAS to reach the same comfort percentage as the NTM 11-2 on applying EN 15251:2007.

The reduction in insulation thickness and its elimination in various elements with respect to the requirements of the NTM 11 produces a comfort increase of $6.4 \%$ (EN) and $34.9 \%$ with CAS. Thus, it surpasses the $74.2 \%$ value obtained by applying EN in the previous section, by $12.9 \%$. Annual temperatures range between $13.7^{\circ} \mathrm{C}$ and $28.3^{\circ} \mathrm{C}$, with an amplitude of $14.6^{\circ} \mathrm{C}$. Hence, the minimum 
temperature would drop $1.4{ }^{\circ} \mathrm{C}$, the maximum temperature $2.4{ }^{\circ} \mathrm{C}$ and annual oscillation $0.9^{\circ} \mathrm{C}$ with respect to the case that complies with the insulation thickness of the NTM 11. It is, therefore, possible to see that overheating problems are significantly reduced, with minimum temperatures falling within the thermal comfort ranges. Further reductions in temperature with consequent improvements in comfort conditions could be achieved using smart windows made with new construction techniques [39].

The reduction of the insulation investment costs is more significant in this case, being $100 \%$ for the ground floor wall and floor, $52.4 \%$ for the top floor wall and $16.6 \%$ for the roof. The total reduction cost is $58.2 \%$ (Table 8 ). It can be seen that the choice of an accurate thermal insulation thickness could significantly increase the annual time in comfort using adaptive models (87.1\% CAS and $80.5 \%$ EN). In this case, the CAS model surpasses the NTM 11 model by $12.9 \%$ considering the result of the EN model for NTM 11 requirements (74.2\%). Moreover, overheating situations are also reduced $17.7 \%$ (EN) and $34.9 \%$ for CAS without an increase in the cold hours if CAS is applied.

\section{Conclusions}

Economic studies on thermal insulation improvements usually consider that houses will demand an amount of energy for air conditioning systems and as a result, when there is the increase of insulation, such consumption will be reduced and it will result in energy savings. In the case of social housing, it is not likely to cause such a direct consumption reduction, as in several cases these are working in free running, except for extremely cold or warm conditions.

The novelty of this research is to open a new field of analysis using adaptive thermal comfort models to evaluate the need of thermal insulation and its thickness. The thermal insulation implementation with the thickness required to meet the standards of the NTM 11-2, means a reduction of the discomfort hours when compared to housing that does not have thermal insulation. This reduction depends on the adaptive comfort model used in the evaluation. The reduction of the annual percentage of hours in discomfort in the analyzed model, as a result of the implementation of thermal insulation, is $20.8 \%$ for EN, $6.4 \%$ to ASHRAE and $-17.8 \%$ for CAS. This difference is based on the increase of indoor operative temperatures.

According to this study, it is possible, by combining the thermal insulation and its thickness, to obtain a similar number of annual hours in thermal comfort using different adaptive comfort models. The evaluation with thermal insulation to meet the requirements of NTM $11-2$ is $59.9 \%$ of the hours in comfort using ASHRAE standard 55-2017 and 74.2\%, if EN 15251:2007 is used.

Reducing the thermal insulation thickness by $10 \mathrm{~mm}$ in the floor plant walls, $25 \mathrm{~mm}$ in the top plant walls, $20 \mathrm{~mm}$ in the roof and $10 \mathrm{~mm}$ in the floor, the comfort percentage of time achieved using CAS is $64.0 \%$ and using ASHRAE is $63.8 \%$. Therefore, the reduction in investment costs in thermal insulation is $28.8 \%$, increasing comfort hours without an excessive change in the dwelling's maximum and minimum temperatures.

On the other hand, the removal of the insulation in the walls of the ground floor and in the floor, and the reduction of $40 \mathrm{~mm}$ in the top floor walls and $40 \mathrm{~mm}$ in the roof supposes a comfort percentage of $87.1 \%$ (CAS) and $80.5 \%$ (EN), surpassing the EN model which considers NTM $11-2(74.2 \%)$. As a result, a reduction in $58.2 \%$ of the investment costs in thermal insulation is established in addition to a significant decrease of overheating situations.

Author Contributions: All the authors contributed equally in the present research.

Funding: This paper is part of the research project CONICYT FONDECYT 3160806 "Study of the feasible energy improvement standard for social housing in fuel poverty by means of post occupational adaptive comfort assessment and its progressive implementation" funded by the Chilean National Commission for Research in Science and Technology.

Acknowledgments: The authors Alexis Pérez-Fargallo and Carlos Rubio-Bellido would like like to acknowledge the VI PPIT-US for their support in this research and its internationalization.

Conflicts of Interest: The authors declare no conflict of interest. 


\section{References}

1. United Nations Environment Programme. Building Design and Construction: Forging Resource Efficiency and Sustainable Development; UNEP: Nairobi, Kenya, 2012.

2. International Energy Agency. World Energy Outlook 2013; IEA: Paris, France, 2013; pp. 1-7.

3. Attia, S.; Carlucci, S. Impact of different thermal comfort models on zero energy residential buildings in hot climate. Energy Build. 2015, 102, 117-128. [CrossRef]

4. Nicol, J.F.; Humphreys, M.A. Adaptive thermal comfort and sustainable thermal standards for buildings. Energy Build. 2002, 34, 563-572. [CrossRef]

5. European Committee for Standardization. Energy Performance of Buildings. Overall Energy Use and Definition of Energy Ratings; EN 15603:2008; CEN: Brussels, Belgium, 2008; pp. 1-45.

6. European Committee for Standardization. Energy Performance of Buildings. Indicators, Requirements, Ratings and Certificates. General Aspects and Application to the Overall Energy Performance; EN 52003-1:2017; CEN: Brussels, Belgium, 2017.

7. Rubio-Bellido, C.; Pérez-Fargallo, A.; Pulido-Arcas, J.A.; Trebilcock, M. Application of adaptive comfort behaviors in Chilean social housing standards under the influence of climate change. Build. Simul. 2017, 10, 933-947. [CrossRef]

8. European Committee for Standardization. Indoor Environmental Input Parameters for Design and Assessment of Energy Performance of Buildings Addressing Indoor Quality, Thermal Environment, Lighting and Acoustics; EN 15251:2007; European Committee for Standardization: Brussels, Belgium, 2007.

9. American Society of Heating, Refrigerating and Air Conditioning Engineers (ASHRAE). ASHRAE Standard 55-2017 Thermal Environmental Conditions for Human Occupancy; ASHRAE Inc., Ed.; American Society of Heating, Refrigerating and Air Conditioning Engineers: Atlanta, GA, USA, 2017.

10. Ministry of Housing and Urbanism of Chile. Estadisticas Históricas. Available online: http://www. observatoriohabitacional.cl/ (accessed on 28 April 2016).

11. Ministry of Housing and Urbanism of Chile. Reglamento del Sistema Integrado de Subsidio Habitacional; DS 01; MINVU: Santiago de Chile, Chile, 2011.

12. Ministry of Housing and Urbanism of Chile. Reglamento del Programa Fondo Solidario de Elección de Vivienda; DS 49; MINVU: Santiago de Chile, Chile, 2011.

13. MOP Decreto Con Fuerza de Ley No 2 Sobre Plan Habitacional. Available online: http://www.sii.cl/pagina/ jurisprudencia/legislacion/basica/dfl2_1.htm (accessed on 16 November 2016).

14. Ministry of Housing and Urbanism of Chile. Ordenanza General de la Ley General de Urbanismo y Construcciones; DS 47; MINVU: Santiago, Chile, 1992.

15. CITEC UBB; DECON UC. Manual de Hermeticidad al Aire de Edificaciones, 1st ed.; TREBILCOCK, M., Ed.; Fondef: Concepción, Chile, 2012.

16. Ministry of Housing and Urbanism of Chile. Exigencias de acondicionamiento térmico de la Ordenanza general de urbanismo y construcciones. In Ordenanza General de la Ley General de Urbanismo y Construcciones; DS 47; MINVU, Ed.; MINVU: Santiago, Chile, 2007.

17. Ministry of Housing and Urbanism of Chile and Building Research Establishment. Estándares de Construcción Sustentable para Viviendas; Building Research Establishment: Santiago, Chile, 2016.

18. Comisión Nacional de Energía Balance Nacional de Energía. Available online: http:/ / datos.energiaabierta. cl/datastreams/91918/bne-2009-distribucion-consumo-total/ (accessed on 16 November 2016).

19. Pérez Fargallo, A.; Calama Rodríguez, J.; Flores Alés, V. Comparativa de resultados de rehabilitación energética para viviendas en función del grado de mejora. Inf. Construcción 2016, 68, 1-11. [CrossRef]

20. Bustamante, W.; Cepeda, R.; Martínez, P.; Santa María, H. Eficiencia energética en vivienda social: Un desafío posible. In Camino al Bicentenario-Propuestas para Chile; Concurso de Políticas Públicas: Santiago, Chile, 2009; pp. 253-282.

21. Cannistraro, G.; Cannistraro, M.; Restivo, R. The Local Media Radiant Temperature for the Calculation of Comfort in Areas Characterized By Radiant Surfaces. Int. J. Heat Technol. 2015, 33, 115-122. [CrossRef]

22. Cannistraro, G.; Cannistraro, M.; Restivo, R. Some observations on the radiative exchanges influence on thermal comfort in rectangular open-space environments. Int. J. Heat Technol. 2015, 33, 79-84. [CrossRef] 
23. Cannistraro, G.; Cannistraro, M.; Restivo, R.; Cannistraro, G.; Cannistraro, M.; Restivo, R. Smart Control of Air Climatization System in Function on the Values of Mean Local Radiant Temperature. Smart Sci. 2016, 0477, 157-163. [CrossRef]

24. Fanger, P.O. Fanger Thermal Comfort: Analysis and Applications in Environmental Engineering; Danish Technical Press: Copenhagen, Denmark, 1970; p. 244.

25. Technical Committee ISO/TC 159. Ergonomics of the Thermal Environment-Estimation of Thermal Insulation and Water Vapour Resistance of a Clothing Ensemble; ISO 9920:2007; International Standardization Organization: Brussels, Belgium, 2007.

26. Technical Committee ISO/TC 159. Ergonomics of the Thermal Environment-Determination of Metabolic Rate; ISO 8996:2004; International Standardization Organization: Brussels, Belgium, 2004.

27. European Commission. Commission Delegated Regulation (EU) No 244/2012 of 16 January 2012 supplementing Directive 2010/31/EU of the European Parliament and of the Council on the energy performance of buildings by establishing a comparative methodology framework for calculating cost-optimal levels of minimum energy performance requirements for buildings and building elements. Off. J. Eur. Union 2012, L 81, 18-36.

28. European Commission. European Commission. Guidelines accompanying Commission Delegated Regulation (EU) No 244/2012 of 16 January 2012 supplementing Directive 2010/31/EU of the European Parliament and of the Council on the energy performance of buildings by establishing a comparative methodology framework for calculating cost-optimal levels of minimum energy performance requirements for buildings and building elements. Off. J. Eur. Union 2012, C 115, 1-28.

29. ASTM International. Standar Practice for Measuring Life-Cycle Costs of Buildings and Building Systems; ASTM E917-05; ASTM International: West Conshohocken, PA, USA, 2015; pp. 1-43.

30. CORFO; ABACO. Sustainable Cost Database. Chilean Economic Development Agency, Chile. Available online: http:/ / abacochile.cl/ (accessed on 29 June 2018).

31. Fanger, P.O. Thermal Comfort-Analysis and Applications in Environmental Engineering; Danish Technical Press: Copenhagen, Denmark, 1970.

32. De Dear, R.J.; Brager, G.S. Thermal comfort in naturally ventilated buildings: Revisions to ASHRAE Standard 55. Energy Build. 2002, 34, 549-561. [CrossRef]

33. International Standardization Organization. Ergonomics of the Thermal Environment-Assessment of the Influence of the Thermal Environment Using Subjective Judgement Scales; ISO 10551:1995; International Standardization Organization: Brussels, Belgium, 1995.

34. Nicol, F.; Humphreys, M. Derivation of the adaptive equations for thermal comfort in free-running buildings in European standard EN15251. Build. Environ. 2010, 45, 11-17. [CrossRef]

35. Humphreys, M.A.; Rijal, H.B.; Nicol, J.F. Updating the adaptive relation between climate and comfort indoors; new insights and an extended database. Build. Environ. 2013, 63, 40-55. [CrossRef]

36. European Commission. Directive 2002/91/EC of the European Parliament and of the council of 16 December 2002 on the energy performance of buildings. Off. J. Eur. Union 2002, 91, 65-71.

37. European Commission. Directive 2010/31/EU of the European Parliament and of the Council of 19 May 2010 on the energy performance of buildings. Off. J. Eur. Union 2010, 31, 13-35.

38. Programa de Estudios e Investigaciones en Energía Estimación del Potencial de Ahorro de Energía, Mediante Mejoramientos de la Eficiencia Energética de los Distintos Sectores. Available online: http: / /www.chilesustentable.net/wp-content/uploads/2014/11/Estimaciones.pdf (accessed on 11 May 2016).

39. Cannistraro, M.; Castelluccio, M.E.; Germanò, D. New sol-gel deposition technique in the Smart-Windows-Computation of possible applications of Smart-Windows in buildings. J. Build. Eng. 2018, 19, 295-301. [CrossRef]

(C) 2018 by the authors. Licensee MDPI, Basel, Switzerland. This article is an open access article distributed under the terms and conditions of the Creative Commons Attribution (CC BY) license (http:/ / creativecommons.org/licenses/by/4.0/). 